\title{
National power and the search for a generalized theory of terrorist target selection: An introduction to the Uyo School
}

\author{
Robert O. Dode and Henry U. Ufomba* \\ Department of Political Science and Public Administration, University of Uyo, Uyo, Akwa Ibom State, Nigeria.
}

Received 23 October, 2013; Accepted 5 September, 2014

\begin{abstract}
The assumption that terrorist organizations (TO) select their target(s) putting into consideration its own limited resources and the impact of the selected target on the national power of the victim state has been the underlying assumption of the Uyo School. In the face of the increasing search to uncover the determinant of terrorist target selection which has become central in terrorism literature does the Uyo School provide a generalized theory on the issue? And are its assumptions robust enough to provide the needed theoretical framework as a research program for more rigorous and scientific study on the subject matter? This paper makes a presentation of the core propositions of the school. It concludes that the school provides the most promising theorization on the subject.
\end{abstract}

Key words: National power, political capacity, economic capacity, demography, terrorist attack, terrorist organization, power foregone, endurance capacity.

\section{INTRODUCTION}

One of the most reoccurring themes in terrorism literature is the search for the structure and rationale in terrorist target selection (TTS). As early as 1998, C.J.M Drake theorizes that there exists a linkage between the ideological base of a terrorist organization (TO) and its target preference since ideology provides the framework through which the TO evaluates its actions on other people and reaction. Ideology therefore lends itself as the moral framework through which terrorists judge the credibility of their actions (Drake, 1998).

Since the September 11 attacks on the United States, there has been unprecedented explosion on scholarly work on the subject matter. These extensive scholarly works concluded that:

1. There exists a linkage between the decision-making process of a terror group and its interaction with the state (Bueno de Mesquita, 2005a, 2005b; McCormick, 2003; Lake, 2002)

2. Terrorist activities (including target selection) are shaped by the resource limitation and the ideology of its supporters (de la Calle and Sanchez-Cuenca, 2007; Lapan and Sandler, 1988)

3. There is a connection between the time of terrorist

*Corresponding a uthor. E-mail: ufomba@gma il.com.

Authors agree that this artic le remain pemanently open access under the terms of the Creative Commons Attribution License 4.0 Intemational Lic ense 
attack and its target and technique choice (Pape, 2003, 2005; Bloom, 2005; Kyudd and Walter, 2002; Berman and Lantin, 2005)

4. There exists a linkage between the state defensive and pre-emptive policy and terrorist target behavior including their target choice (Bandyopadhyay and Sandler, 2011; Brandt and Sandler, 2010; Bernulandt and Polborn, 2010; Sander, 2010)

5. Terrorist groups make target choice(s) that creates dynamics of action-repression which arouses sympathy for its cause from the populace (de Figueiredo and Weingast, 2001)

6. Target choice(s) are selected by TO based on its capacity to draw media attention (Hoffman, 2010)

7. Terrorist groups choose targets that neutralize government advantage over them in their 'bargaining interaction' for public support (Nemeth, 2010)

8. There is a linkage between terrorist target choice and the state's allocation of security resources (Mathews and Loweberg, 2012; Power 2002; Berhandt and Polborn, 2010; Brandt and Sandler, 2010).

More recently a perspective on the subject has emerged known as the Uyo School. This school of thought is of the opinion that TO has limited human and material resources compared to the state. In its interaction with the state TO aims at forcing the victim state (VS) to make concession to its demand(s) by attacking its core components of national power which are identified by power transition theorists to include political, economic and demographic capacity, in order to optimize its limited resources. This suggestion appears to be logically since it presents TO as having the capability of making rational choice in its target selection in face of its limited resources. But do this suggestion and other core assumptions of the school constitute a veritable framework in the complex art of explaining and maybe predicting terrorist target(s) in the future? Does the Uyo School lend itself as a generalized theory in the expanding discipline of terrorism studies which compared to other social sciences has been found wanting in theoretical sophistication and methodology? This paper will answer these questions. It will present the core assumptions of the Uyo School as a veritable research program.

\section{The theoretical foundation of the Uyo School}

To make a proper appraisal of the postulation of the Uyo School on terrorist target selection, it is imperative to first and foremost bring into limelight the theoretical framework upon which its assumptions were developed.

The school is an extension of the core tenets of the Power Transition Theory (PT) which is an IR research program into the realm of terrorism studies. The school replicated the success of PT which is one of the most robust theoretical and empirical explanations of war and peace, and which stands out among the theories of international conflict and co-operation (Eminue and Ufomba, 2011; Lemke and Werner, 1996; Tammen et al., 2000; Kim, 1991, 1992, 1996; Abdollhain and Kang, 2008).

PT was first put forward by A.F.K Organski in 1958 to explain the causes of conflict between major powers. To the adherents of this theory, the international system is a hierarchical structured system wherein the position of a state is determined by its national power. And national power is made up of three core components- political capacity, economic capacity and demography. And as the national power of a state increases or decreases in relation to other states, its status in the hierarchy changes. When a state advanced to the position of a major power it will challenge the status quo if it does not suit its own interest in other to alter it - a situation which accounts for conflict between it and the existing power whose interest is to maintain the status quo.

Since it has been developed into a more generalized theory of war and peace by Kugler and Lemke (1996), PT has been extended as a research program to explain virtually all known phenomena both in inter-state and intra-state interaction. For example, Lemke (2002) applied it in the explanation of the duration of conflict at regional level. It was adopted in the correct prediction of the rise of China and India to major power status by Wilson and Purushothaman (2003), Maddison (2003), Organski (1958) and Fogel (2007). Other successful application of PT includes Kang and Kugler's integrated formal deterrence structure using a game theoretic approach (Kang and Kugler, 2007), Abdollahian and Kang's analysis of conflict in multiple level among subnational, national and regional actors (Abdollahian and Kang, 2008), Alsharabati and Kugler's theorization on the stability of deterrence building (Alsharabati and Kugler, 2008), Abdollahian's development of a system of nonlinear differential equations to simulate the structural conditions that lead to inter-state conflict or co-operation (Abdollahian, 1996) among other breakthrough in scholarship (Coan and Kuglar, 2008; Arbetman-Rabinwitz and Johnson, 2008; Feng et al., 2008). Recognizing PT as a powerful framework of analysis Dicocco and Levy concluded that PT is a lively and expanding research program that has moved forward in several important substantive directions (Tammen, 2008). Most theoretical extensions of power transition principles have generated novel predictions, many of which are empirically collaborated, and proponents of the research program have been particularly good at developing improved operational measures of key theoretical concepts (Dicoco and Levy, 2003:147-148).

The Uyo School therefore situates itself within this successful research program by adopting its core concept of national power to explain the factors that 
shapes the target choice of terrorist organizations in its interaction with the state.

\section{Tenets of the Uyo School: An evaluation of its strength and weakness}

The foundation of the Uyo School was first laid by Okon Eminue and Henry Ufomba in their seminal paper titled 'Modeling Terrorist Target Selection: Organski's Power Transition Theory' and expanded into a more encompassing and elaborate model by Dode and Ufomba (forthcoming). The school developed its theory of TTS by moving Organski's Power Transition Theory (PT) from its traditional realm as an IR theory to the more restricted borders of terrorism studies. This was achieved by employing PT phenomenon of national power to model the linkage between terrorist target choices and the VS (Ufomba, 2013). It therefore suggests that the same variables ${ }^{1}$ that determine a VS's status in the international hierarchy also determine its relationship with a terrorist organization in the event of the latter's selection of target (Eminue and Ufomba, 2011). In their work, Dode and Ufomba (forthcoming) extended the model by incorporating into it the dual concepts of endurance capacity and power forgone ${ }^{2}$ to simulate the determinants of a VS post-attack behavior using a gametheoretic approach. With this extension the theorization of the school can be summed to contain five core assumptions which are:

Assumption 1: Terrorist groups lack the immerse resources of the state both in human and material perspective. Hence, to achieve its aim they optimize their resources through the selection of critical targets that will compel VS to make concession. The cost of the attack is lower than the damage done on the VS.

Assumption 2: Critical targets are the three core components of the national power of VS. These components are its' political, economic and demographic capacity ${ }^{3}$.

Assumption 3: VS has the capacity to maintain its stance after been attacked by TO. This is its endurance capacity.

Assumption 4: The endurance capacity of VS is a function of its willingness to sacrifice its national power to maintain its stance on a particular demand. The loosed power is its power forgone.

Assumption 5: The endurance capacity of VS is its breaking point beyond which it is likely to make concession to TO on a particular demand and at a particular time/period.

From the above five assumptions the school theorized beyond 'why' and 'how' a TO selects its target but also it laid down the rational expectation of a VS behavior in its post-attack interaction with TO. The 'why' TO chooses its target $^{4}$ is its rational behavior of resource. Its broad perception encompasses previous postulations and goes beyond it since available data on terrorist targets worldwide point the core components of national power has been the target of most terrorist attacks globally (Table 1). Well this data does not present itself as a perfect statistical analysis but it suggests the prospect of these assumptions unveiling itself as a robust and generalized theory of terrorist target selection.

As stated above, while these assumptions have not been subjected to rigorous empirical analysis nevertheless its logic presents itself more than any other theory as a veritable framework for future research work on terrorist selection since previous postulations are limited to variables that are not robust enough to explain terrorist target selection on a wide spectrum of cases in comparison with the Uyo School.

\section{Conclusion}

Although terrorist organizations conduct their activities as a clandestine group, it has been an increasing interest in terrorism literature to uncover the factors or determinants that shape its decision making process in general and its target choice in particular. To this end there has been avalanche theorization as the subject matter which spans from Drake's view that ideology plays a key role in shaping target choice to Hoffman's 'media attraction' as a veritable stimulant in terrorist target selection among others. Situated within this quest, the Uyo School presents itself as a powerful theory to explain terrorist target choice. Its proposition that national power is the main target choice of a TO in its quest to force VS to make concession to its demand(s) is logical and in line with available data as shown in Table 1. The robustness of its assumptions also explains the post-attack rational behavior of VS. Hence, its theorization is an important contribution to the literature since it gives room for future extension and modification making it a superb framework for future research in the field.

\section{ENDNOTES}

1. The variables here are PT's established components of national power which are political capacity, economic capacity and demography (see, Abdollahian and Kang 2008; Tammen 2008; Tammen et al 2000 among others)

2. In the taxonomy of the Uyo School the concept of 'power forgone' is used to refer to the amount of national power as tate is willing to sacrifice at a particular time as are sult of a terrorist threat or attack in the process of 
Table 1. Terrorist attacks worldwide and their relation to national power demography (Dem), economic capability (ECO), political capability (POL).

\begin{tabular}{lcl}
\hline Targets & Number of attacks & Relation to national power \\
\hline Private Citizens and Property & 17010 & DEM/ECO/Pol \\
Business & 12558 & ECO \\
Govt (General) & 11059 & DEM/ECO/POL \\
Military & 11007 & POL \\
Police & 9802 & POL \\
Transportation & 4132 & ECO \\
Journalistic/Media & 1694 & POL \\
Religious Figures/Institutions & 1609 & - \\
Educational Institution & 1490 & ECO/POL/DEM \\
Others & 1426 & - \\
Airport/Airlines & 933 & ECO \\
Unknown & 913 & - \\
Terrorist & 842 & POL \\
NGO & 739 & ECO/POL \\
Telecommunication & 453 & ECO \\
Tourists & 289 & ECO \\
Abortion related & 261 & - \\
Maritime & 159 & ECO \\
Food/Water Supply & 108 & DEM \\
\hline
\end{tabular}

Source: Eminue and Ufomba (2011) and Global Terrorism Database of the University of Maryland.

resisting terrorist demands. In the other hand 'endurance capacity' is the point at which $V$ Sisno longer able or willing to sacrifice anymore of its national power in its refusal to TO's demand. It is assumed that beyond its endurance capacity VS is likely to make concession.

3. These concepts were used in the context of PT parlance.

4. The expectation here is that TO is a rational decisionmaker that makes the best possible choice at a particular time from a wide range of choices putting into consideration its limited resources and its ultimate aim of satisfying its own want.

\section{Conflict of Interests}

The authors have not declared any conflict of interests.

\section{REFERENCES}

Abdollahian M, Kang K (2008). "In Search of Structure: The Nonlinear Dynamics of Power Transitions". Int. Interactions 34(4):337-357.

Arbetman - Rabinowitz M, Johnson K (2008). "Power Distribution and Oil in the Sudan: Will the Comprehensive Peace Agreement Turn the Oil Curse into a Blessing?" Int. Interactions 34(4):382 - 401.

Bandyopadhyay S, Sandler T (2011). "The Interplay Between the Preemptive and Defensive Counter-terrorism Measures: A Two-Stage Game" Economics 78:546-564.
Berman E, Latin D (2005)."Hard Targets: Theory and Evidence on Suicide Attacks" NBER WorkingPaper 11740.

Bloom M (2005). Dying to Kill: The Allure of Suicide Terror. New York. Columbia University Press.

Brandt P, Sandler T (2010). "What do Transnational Terrorists Target? Has it changed? Are we safer?" J. Conf. Res. 54:214-236.

Bueno de Mesquita E (2005a). "The Terrorist Endgame: A model with Moral Hazard and Learning" J Conf. Res. 49:237-258.

Bueno de Mesquita E (2005b) "Conciliation,counter-terrorism and Patterns of Terrorist Violence" Int. Org. 59:145-176.

Coan TG, Kugler T (2008) "The Politics of Foreign Direct Investment: An Interactive Framework" Int. Interactions 34(4):402-422.

de Figueiredo R, Weingast B (2001). "Vicious Cycle: Endogenous Political Extremism and Political Violence" Paper available at (http://slantchev.ucsd.edu/courses/pdf/figueiredo-vicious.pdf) University of California, San Diego [Date of consultation: October 27, 2012].

de la Calle L, Sanchz-Cuneca I (2006). "The Production of Terrorist Violence: Analyzing Target Selection in the IRS and ETA" Paper available http://www.yale.edu/macmillan/ocvprogram/OCV_Calle.pdf

Dode R, Ufomba H (2014). "A Game-Theoretic Assumption on the Nature of The Interaction Between Victim State And Terrorist Organization Using The Eminue-Ufomba Model. J. Conflictol.. Spring 5(1). $\quad$ http://journals.uoc.edu/index.php/journal-ofconflictology/article/viewFile/vol5iss1-joc/vol5iss1-joc-en

Drake CJM (1998) "The Role of Ideology in Terrorist's Target Selection". Terrorism Pol. Violence 10:53-85.

Eminue O, Ufomba H (2011) "Modeling Terrorist Target Selection: Organski's Power Transition Theory" Def. Sec. Anal. 27(4):375-382.

Feng Y, Kugler J, Swaminathom S, Zak P (2008). "Path to Prosperity: The Dynamics of Freedom and Economic Development" Int. Interactions 34(4):423-441. 
Fogel RW (2007). Capitalism and Democracy in 2040: Forecasts and Speculation. National Bureau of Economics Research.

Hoffman AM (2010). "Voice and Silence" Why Groups Take Credit For Acts of Terror". J. Peace Res 47(5):615-626.

Kang K, Kugler J (2007) "Conditional Deterrence: Why Do Actors Engage in Extreme Wars?" Paper delivered at the Annual Meeting of the Peace Science Society. Columbia, Sc. November 2-4.

Kim W (1996). "Power Parity, Alliance and War from 1648 to 1975" In: J. Kugler and P. Lemke, eds., Parity and War: Evaluations and Extensions of the War Ledger. Ann Arbor, MI: University of Michigan Press pp.93-105.

Kim W (1991). "Alliance Transitions and Great Power War" Am. J. Pol. Sci. 35:833-850.

Kim W (1992) "Power Transitions and Great Power War from Westphalia to Waterloo" World Pol. 45:153-172.

Kugler J, Lemke D (1996). Parity and War: Evaluations and Extensions of the War Ledger. Ann Arbor: University of Michigan Press.

Lake D (2002). "Rational Extremism: Understanding Terrorism in the Twenty-First Century" Dialog-Int. Org. 1(1):15-29.

Lapan H, Sandler T (1988). "To Bargain or not to Bargain: That is the Question". Am. Econ. Rev. 78:16-31.

Lemke D (2002). Regions of War and Peace. New York: Cambridge University Press.

Lemke D, Werner S (1996). "Power Parity, Commitment to change and War" Int. Stud. Q. 40:235-260.

Maddison A (2003) The World Economy: Historical Statistics. OECD.

Mathews T, Lowenberg A (2012). "The Interdependence between Homeland Security Efforts of A State and A Terrorist's choice of Attack" Conf. Manage. Peace Sci. 29:195-218.

Nemeth S (2010). A Rationalist Explanation of Terrorist Targeting. Ph.D Dissertation. University of lowa.
Organski AFK (1958). World Politics. New York. Alfred A. Knopf.

Pape R (2003). "The Strategic Logic of Suicide Terrorism". Am. Pol. Sci. Rev. 97:343-361.

Pape R (2005). Dying to Win: The Strategic of Suicide Bombing. New York. Random House.

Tammen R (2008). "The Organski Legacy: A Fifty Year Research Program" Int Interactions 34(4):314-332.

Tammen RL (2008). "The Organiski Legacy: A Fifty-Year Research Program" Dicocco and Levy ed Int. Interactions 34 (4):314-332.

Tammen RL, Kugler J, Lemke D, Stam A, Abdollahian M, ALsharabati C, Efird B, Organski AFK (2000). Power Transitions: Strategies for the Twenty-First Century. New York. Chatham House.

Ufomba $\mathrm{H}$ (2013). National Power AS A Critical Terrorist Target Choice: A Dataset of The Activities of The JamaaAhl al-Sunnah li-da'wawa alJihad (Boko Haram) Sect in Nigeria (2009-2012) Berkeley Electronic Press. Available at http://www.academia.edu/4754244/National_Power_As_A_Critical_T errorist_Target_Choice_A_Dataset_on_The_Activities_of_The_Jama aAhl al-Sunnah li-dawawa al-

Jihad_Boko_Haram_Sect_in_Nigeria_2009-2012

Wilson $\bar{D}$, Purushothaman $\bar{R}$ (2003). Dreaming with the BRICS: The Path to 2050, Global Economics paper 99, Goldman Sachs. 